\title{
Soluble Spike DNA Vaccine Provides Long-Term Protective Immunity against SARS-CoV-2 in Mice and Nonhuman Primates
}

\author{
Yong Bok Seo ${ }^{1}$, You Suk Suh ${ }^{2}$, Ji In Ryu ${ }^{1}$, Hwanhee Jang ${ }^{1}$, Hanseul Oh ${ }^{3}$, Bon-Sang Koo ${ }^{3}$, Sang-Hwan Seo ${ }^{4}$, \\ Jung Joo Hong ${ }^{3}$, Manki Song ${ }^{4}$, Sung-Joo Kim ${ }^{5}$ and Young Chul Sung ${ }^{1,2, *}$
}

Citation: Seo, Y.B.; Suh, Y.S.; Ryu, J.I.; Jang, H.; Oh, H.; Koo, B.-S.; Seo, S.-H.; Hong, J.J.; Song, M.; Kim, S.-J.; et al. Soluble Spike DNA Vaccine Provides Long-Term Protective Immunity against SARS-CoV-2 in Mice and Nonhuman Primates. Vaccines 2021, 9 , 307. https://doi.org/10.3390/ vaccines 9040307

Academic Editors

Vasso Apostolopoulos, Steven B. Bradfute and Scott Anthony

Received: 10 February 2021

Accepted: 20 March 2021

Published: 24 March 2021

Publisher's Note: MDPI stays neutral with regard to jurisdictional claims in published maps and institutional affiliations.

Copyright: (c) 2021 by the authors. Licensee MDPI, Basel, Switzerland. This article is an open access article distributed under the terms and conditions of the Creative Commons Attribution (CC BY) license (https:/ / creativecommons.org/licenses/by/ $4.0 /)$.
1 Research Institute, SL VaxiGen Inc., Korea Bio Park, Seongnam 13488, Korea; ybseo@slvaxigen.com (Y.B.S.); jiryu@slvaxigen.com (J.I.R.); hhjang@slvaxigen.com (H.J.)

2 Research Institute, Genexine Inc., Korea Bio Park, Seongnam 13488, Korea; yssuh@genexine.com

3 National Primate Research Centre, Korea Research Institute of Bioscience and Biotechnology, Cheongju, Chungcheongbuk 34141, Korea; seul3198@kribb.re.kr (H.O.); porco9@kribb.re.kr (B.-S.K.); hong75@kribb.re.kr (J.J.H.)

4 Science Unit, International Vaccine Institute, Seoul 08826, Korea; SangHwan.Seo@ivi.int (S.-H.S.); mksong@ivi.int (M.S.)

5 GenNBio Inc., Seoul 06026, Korea; sungjoo.kim@gennbio.com

* Correspondence: ycsung@postech.ac.kr

\begin{abstract}
The unprecedented and rapid spread of SARS-CoV-2 (severe acute respiratory syndromecoronavirus-2) has motivated the need for a rapidly producible and scalable vaccine. Here, we developed a synthetic soluble SARS-CoV-2 spike (S) DNA-based vaccine candidate, GX-19. In mice, immunization with GX-19 elicited not only S-specific systemic and pulmonary antibody responses but also Th1-biased T cell responses in a dose-dependent manner. GX-19-vaccinated nonhuman primates seroconverted rapidly and exhibited a detectable neutralizing antibody response as well as multifunctional CD4+ and CD8+ T cell responses. Notably, when the immunized nonhuman primates were challenged at 10 weeks after the last vaccination with GX-19, they had reduced viral loads in contrast to non-vaccinated primates as a control. These findings indicate that GX-19 vaccination provides a durable protective immune response and also support further development of GX-19 as a vaccine candidate for SARS-CoV-2.
\end{abstract}

Keywords: COVID-19; DNA vaccine

\section{Introduction}

Severe acute respiratory syndrome coronavirus-2 (SARS-CoV-2) emerged towards the end of 2019 as a causative agent of pneumonia in the city of Wuhan in China [1]. Since its emergence, the global situation has been dynamically evolving, and on 30 January 2020, the World Health Organization declared coronavirus disease 2019 (COVID-19) as a public health emergency of international concern (PHEIC), and it was declared as a global pandemic on 11 March 2020. Disease symptoms range from mild flu-like to severe cases with life-threatening pneumonia [2]. Unlike its predecessors of novel betacoronavirus such as SARS-CoV and MERS-CoV, SARS-CoV-2 transmits efficiently from person to person. Due to the high transmissibility and extensive community spread, SARS-CoV-2 has already caused nearly 20 million infections and over 700,000 deaths as of August 2020 [3]. It is estimated that until $\sim 60$ to $70 \%$ of people develop herd immunity, achieving sufficient control of SARS-CoV-2 to resume normal activities is unlikely [4]. Therefore, the rapid development of vaccines or other immunomodulating agents [5] against SARS-CoV-2 is important to change the global epidemiology of this virus.

The four major structural proteins of SARS-CoV-2 are the spike (S) protein, envelope $(\mathrm{E})$ protein, membrane $(\mathrm{M})$ protein, and nucleocapsid $(\mathrm{N})$ protein, which are essential 
for the virus assembly and infection [6]. The $\mathrm{S}$ protein is an attractive target for vaccine design because it plays crucial roles in receptor binding, fusion, and viral entry into the host cell during the infection process. Proteolytic cleavage of the $S$ protein generates two subdomains, S1 and S2, that are responsible for host cell angiotensin-converting enzyme 2 (ACE2) receptor binding and host cell membrane fusion, respectively. While the S2 domain is conserved across human coronaviruses, the S1 domain is divergent across the coronaviruses [7]. It has recently been reported that a vaccine strategy based on the $\mathrm{S}$ antigen can prevent SARS-CoV-2 infection and disease in a mouse model [8]. Moreover, studies in rhesus macaques have shown that vaccine strategies based on the $S$ antigen can prevent SARS-CoV-2 infection and disease in this relevant animal model $[9,10]$, indicating that the $S$ antigen may be sufficient as a vaccine immunogen to elicit SARS-CoV-2 protective immunity.

The urgent need for vaccines prompted an international response, with the development of more than 170 candidate SARS-CoV-2 vaccines within the first 7 months of 2020 [11]. In order to achieve an effective and rapid vaccine response against emerging viruses, a manufacturing and distribution platform that can shorten the time to product availability as well as rapid vaccine design is important. While it typically takes more than several months to produce cell lines and clinical-grade subunit proteins, nucleic acid vaccines can be produced in weeks $[12,13]$. In addition, DNA-based vaccines do not require a cold chain, making them a great alternative to the availability of important, life-saving vaccines in resource-poor areas of the world. There have been studies over the past decades to improve the efficacy of DNA vaccines, and as a result, many improvements in efficacy have been made [14]. In addition to prophylactic DNA vaccines against viral infections such as MERS-CoV and Zika virus, a therapeutic DNA vaccine against cancers has been demonstrated in several clinical trials [15-21].

Here, we explored the potential of a soluble SARS-CoV-2 S DNA vaccine candidate, designated GX-19. Vaccination with GX-19 elicits a concurrent humoral response and Th1biased immune responses in both mice and nonhuman primate (NHP) models. Notably, the vaccine drives potent cellular and humoral responses in NHPs, including neutralizing antibodies that provide potent protective efficacy against SARS-CoV-2 infection. The data demonstrate that the immunogenicity of this DNA vaccine supports the clinical development to advance the development of this DNA vaccine in response to the current global health crisis.

\section{Results}

\subsection{Construction and Immunogenicity of SARS-CoV-2 DNA Vaccines}

The sequence for the SARS-CoV-2 $\mathrm{S}$ protein was generated after analysis of the $\mathrm{S}$ protein genomic sequence, which was retrieved from the NCBI SARS-CoV-2 resource. The full-length or entire ectodomain of the $S$ gene was codon optimized for increased antigen expression in mammalian cells and the N-terminal tissue plasminogen activator (tPA) signal sequence was added. The insert was then subcloned into the pGX27 vector [22] and the resulting plasmid was designated as pGX27-S and pGX27-S ${ }_{\Delta \mathrm{TM}}$ (Figure 1a). 
a

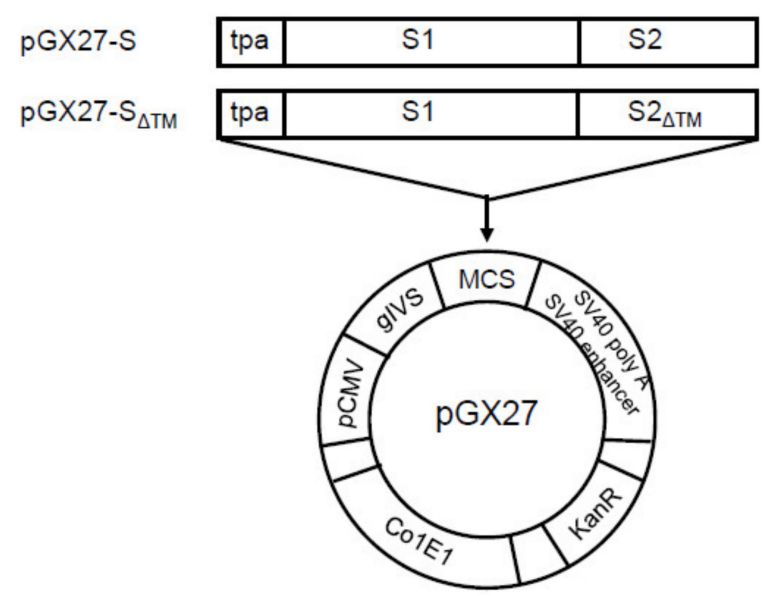

b

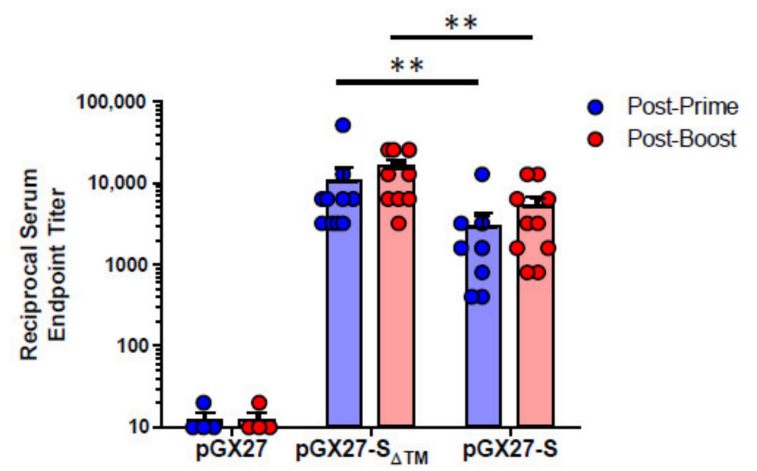

Figure 1. Diagram and immunogenicity of SARS-CoV-2 DNA vaccines. Schematic diagram of COVID-19 DNA vaccine expressing soluble SARS-CoV-2 S protein $\left(\mathrm{S}_{\Delta \mathrm{TM}}\right)$ or full-length SARS-CoV-2 S protein (S) (a). BALB/c mice $(n=4-10 /$ group) were immunized at weeks 0 and 2 with pGX27-S $\Delta$ TM, pGX27-S, or pGX27 (empty control vector) as described in the Methods. Sera were collected at 2 weeks post-prime (blue) and 2 weeks post-boost (red) and evaluated for SARS-CoV-2 S-specific IgG antibodies (b). All data are represented as individual values. ${ }^{* *} p<0.01$ as determined by the Mann-Whitney test.

To assess the immunogenicity of two candidate DNA vaccines, we immunized sixweek-old female BALB/c mice intramuscularly (IM) twice at 2-week intervals. As indicated in Figure $1 b$, immunization with both of the DNA vaccine candidates induced a robust $S$ protein-specific antibody response compared to the control. Interestingly, there were higher antibody titers in the pGX27-S $S_{\triangle T M}$ group than in the pGX27-S group at both post-prime and post-boost. These results are not consistent with the previous report that demonstrated a higher binding antibody in full-length S DNA-vaccinated macaques compared to $S_{\Delta T M}$ DNA-vaccinated macaques [9].

\subsection{GX-19 Induces Strong Humoral and Cellular Immune Responses in Mice}

pGX27-S $S_{\Delta \mathrm{TM}}$, named GX-19, was therefore selected as the vaccine candidate to advance to immunogenicity and efficacy studies. The immunization with GX-19 elicited significant serum IgG responses against the $S$ protein in a dose-dependent manner (Figure 2a). GX-19 vaccination elicited an S-specific IgG response in the bronchoalveolar lavage (BAL) fluid (Figure 2b). Live virus neutralizing titers were also evaluated in BALB/C mice following the same GX-19 immunization regimen. Consistent with the $\mathrm{S}$ binding antibody response, neutralizing activity was elicited by GX-19 (Figure 2c).

Given that severe SARS-CoV is associated with a Th2-biased immune response with an inadequate Th1 response [23-25], we evaluated the balance of Th1 and Th2 responses. Although BALB/c mice tend to develop a more Th2-biased response after vaccination [26], GX-19 induced a Th1-biased immune response as indicated by higher IgG2a/b responses when compared to IgG1 regardless of vaccination doses (Figure 3a,b). We also directly measured cytokine patterns in vaccine-induced $\mathrm{T}$ cells by cytometric bead array. GX-19induced T cells secreted large amounts of IFN- $\gamma$, TNF- $\alpha$, and IL-2 but did not secrete IL-4 or IL-5 (Figure 3d). At 2 weeks after the boost vaccination, spleens were harvested and S-specific T cell responses were measured by IFN- $\gamma$ ELISPOT. Mice immunized with 5, 15, and $45 \mu \mathrm{g}$ of GX-19 exhibited a dose-dependent splenic T cell response with mean IFN- $\gamma$ spots per $10^{6}$ cells of 542, 872, and 1932, respectively (Figure 3c). To gain further insight into the responses of GX-19-induced $\mathrm{T}$ cell responses, we also measured the frequency of $\mathrm{T}$ cells producing multiple cytokines by intracellular cytokine staining (ICS). GX-19 vaccination exhibited a significantly higher percentage of S-specific CD4 ${ }^{+} \mathrm{T}$ cells or $\mathrm{CD} 8^{+} \mathrm{T}$ cells secreting IFN- $\gamma$, TNF- $\alpha$, and IL-2 (Figure 3e; Supplementary Figure S1). 
(a)

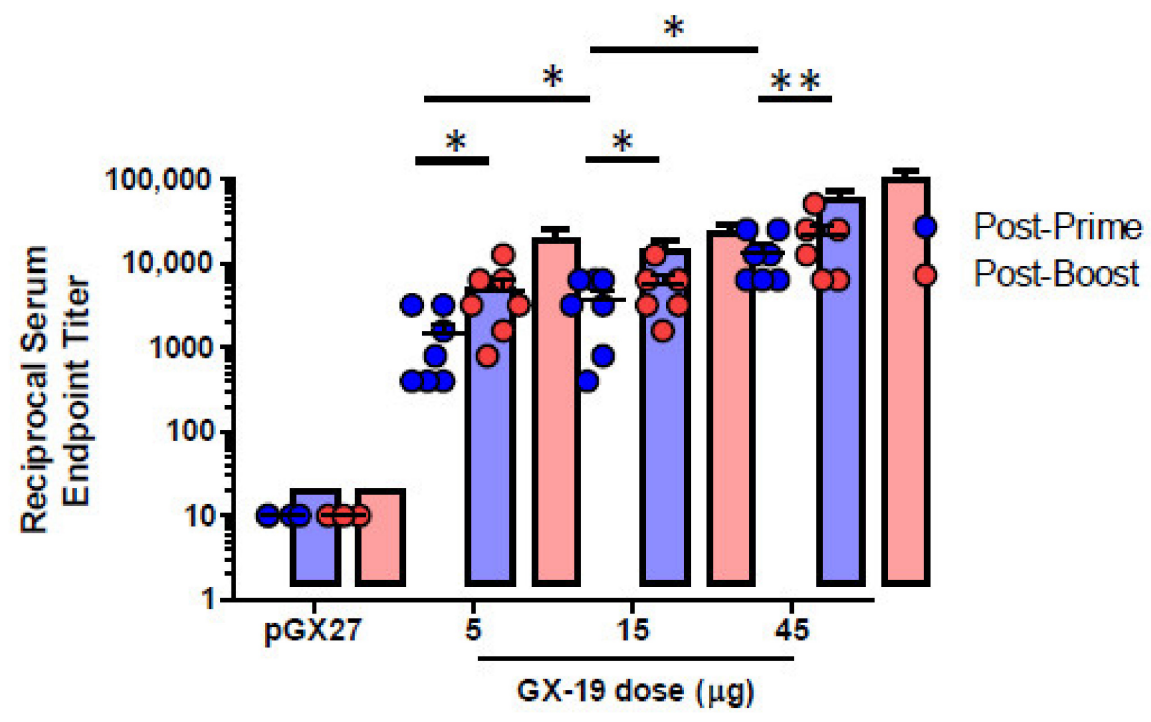

(b)

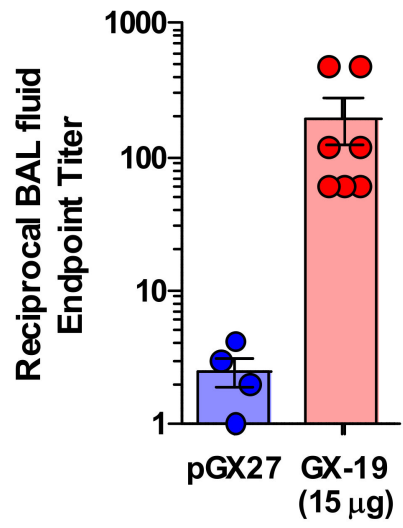

(c)

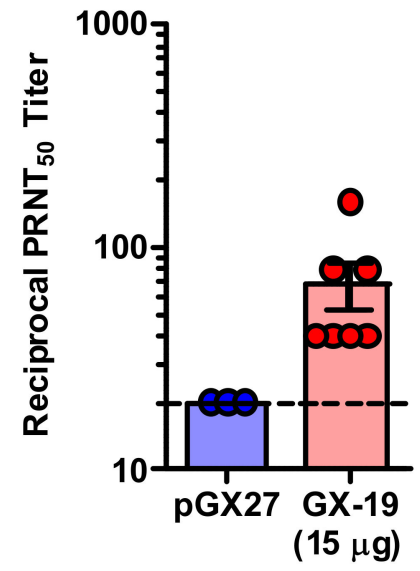

Figure 2. GX-19 elicits robust binding and neutralizing antibody responses in mice. BALB/c mice ( $n=4-7$ /group) were immunized at weeks 0 and 2 with indicated doses of GX-19 or pGX27 as described in the Methods $(\mathbf{a}-\mathbf{c})$. Sera were collected at 2 weeks post-prime (blue) and 2 weeks postboost (red) and assessed for SARS-CoV-2 S-specific IgG antibodies by ELISA (a), and for post-boost sera, neutralizing antibodies against SARS-CoV-2 live virus (c). Bronchoalveolar lavages (BALs) were collected at 2 weeks post-boost and assayed for SARS-CoV-2 S-specific IgG antibodies by ELISA (b). Data representative of two independent experiments. All data are represented as individual values. ${ }^{*} p<0.05,{ }^{* *} p<0.01$ as determined by the Mann-Whitney test. 


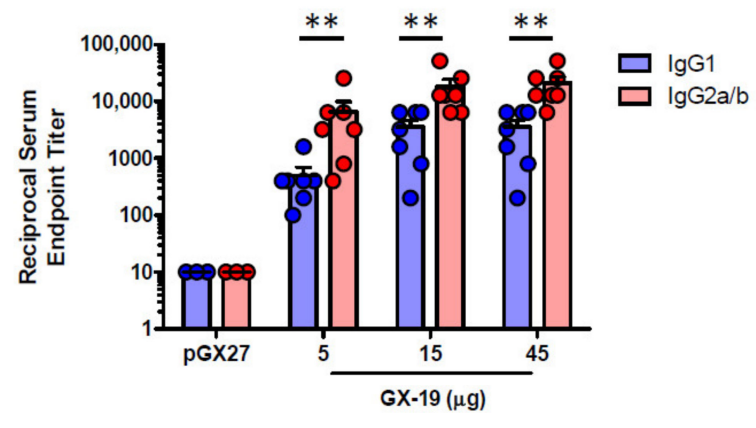

(a)

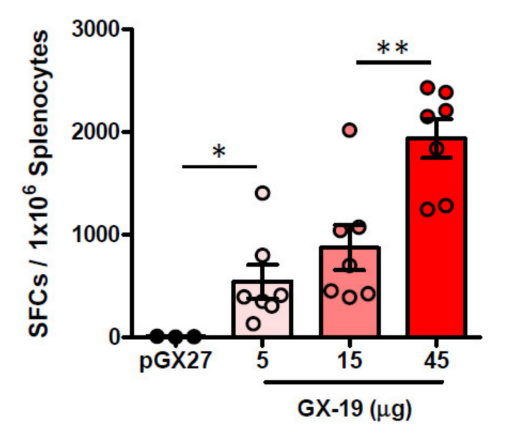

(c)

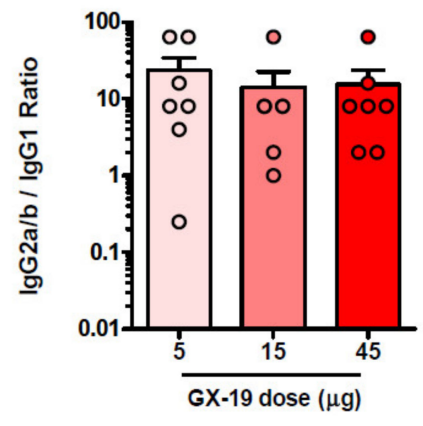

(b)

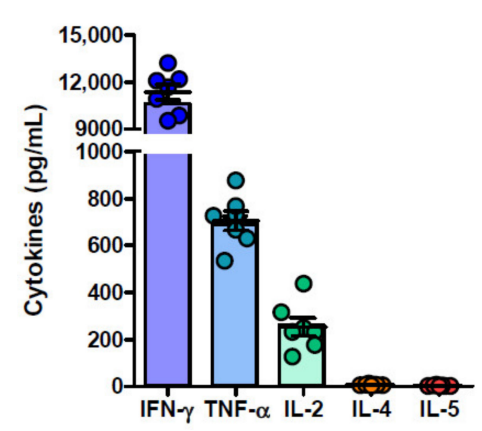

(d)
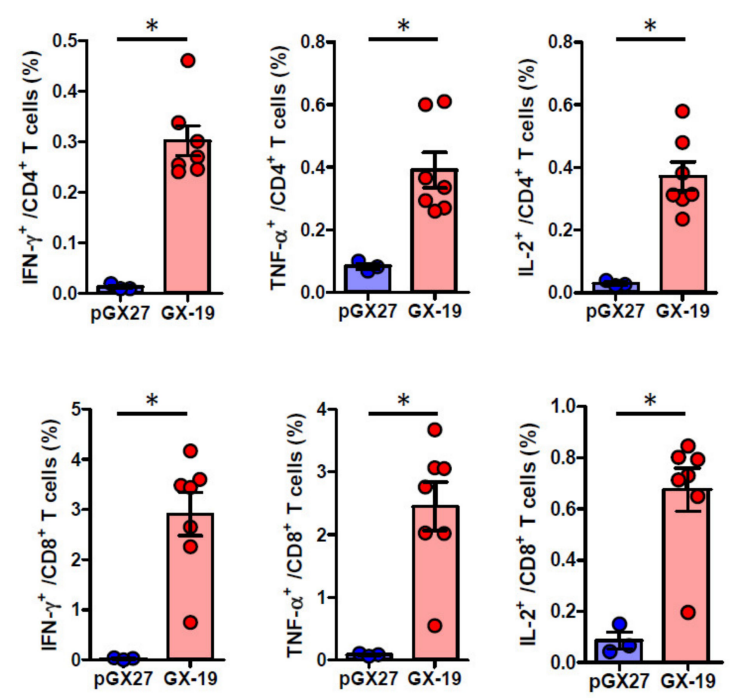

(e)

Figure 3. Immunization with GX-19 elicits Th1-biased T cell responses in mice. BALB/c mice $(n=3-7 /$ group $)$ were immunized at weeks 0 and 2 with indicated doses of GX-19 or pGX27 (empty control vector) as described in the Methods $(\mathbf{a}-\mathbf{c})$. Sera were collected at 2 weeks post-boost and assessed for SARS-CoV-2 S-specific IgG1 and IgG2a/b. Endpoint titers (a), and endpoint tier ratios of $\operatorname{IgG} 2 \mathrm{a} / \mathrm{b}$ to $\operatorname{IgG1}(\mathbf{b})$ were calculated. At 2 weeks post-boost, mouse splenocytes were isolated and re-stimulated with peptide pools spanning the SARS-CoV-2 S protein ex vivo. Indicated cytokines in the supernatants of culture were quantified using a Th1/Th2 cytometric bead array kit. Mean value of the medium alone background (mean \pm s.d., pg mL ${ }^{-1}$ ) was $19.17 \pm 8.61$ for IFN- $\gamma, 57.12 \pm 6.53$ for TNF- $\alpha, 33.10 \pm 6.72$ for IL-2, $7.83 \pm 0.45$ for IL-4, and $4.66 \pm 0.13$ for IL-5 (d). T cell responses were measured by IFN- $\gamma$ ELISPOT in splenocytes stimulated with peptide pools spanning the SARS-CoV-2 S protein. Shown are spot-forming cells (SFC) per $10^{6}$ splenocytes (c). Cells were stained for intracellular production of IFN- $\gamma, \mathrm{TNF}-\alpha$, and IL-2. Shown are the frequency of S-specific CD4 ${ }^{+}$or CD8 ${ }^{+} \mathrm{T}$ cells after subtraction of background (DMSO vehicle, Sigma-Aldrich, St. Louis, MO, USA) (e). Data representative of two independent experiments. All data are represented as individual values. ${ }^{*} p<0.05,{ }^{* *} p<0.01$ as determined by the Mann-Whitney test. 


\subsection{GX-19 Elicits Robust Humoral and Cellular Immune Responses in NHPs}

To investigate whether GX-19 was capable of inducing immune responses in an NHP model, three macaques were vaccinated with electroporation (EP)-enhanced delivery at weeks 0,3 , and 5.5 (day 39) with GX-19. Blood was collected at weeks 0, 5.5, 8, and 13.5 (day 95) to monitor vaccine-induced immune responses. The binding ELISA results showed that all three macaques immunized with GX-19 seroconverted after a single immunization with anti-S IgG titers that tend to be increased by boosting vaccination (Figure $4 \mathrm{a}$ ). In addition, sera collected at weeks $0,5.5,8$, and 13.5 were further analyzed for neutralization of wild-type SARS-CoV-2 (Korea centers for disease control and prevention) by the $50 \%$ plaque reduction neutralization test $\left(\mathrm{PRNT}_{50}\right)$. Three macaques immunized with GX-19 displayed elevated neutralization titers with mean PRNT Po $_{50}$ titers of 1:285 (at week 5.5) and 1:996 (at week 8). However, the mean PRNT 50 titers at week 13.5 (2 weeks before virus infection) were higher than the baseline level but were lower than those detected at week 8 (Figure 4b).

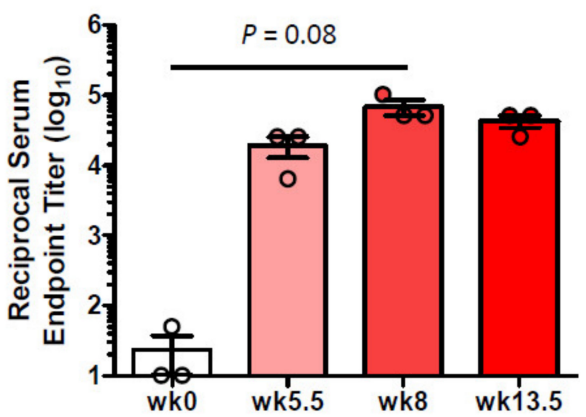

(a)

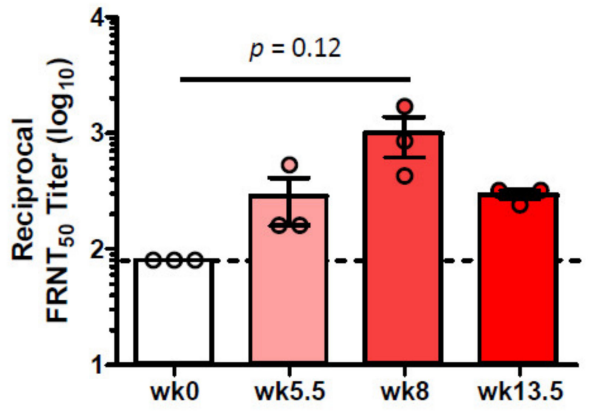

(b)
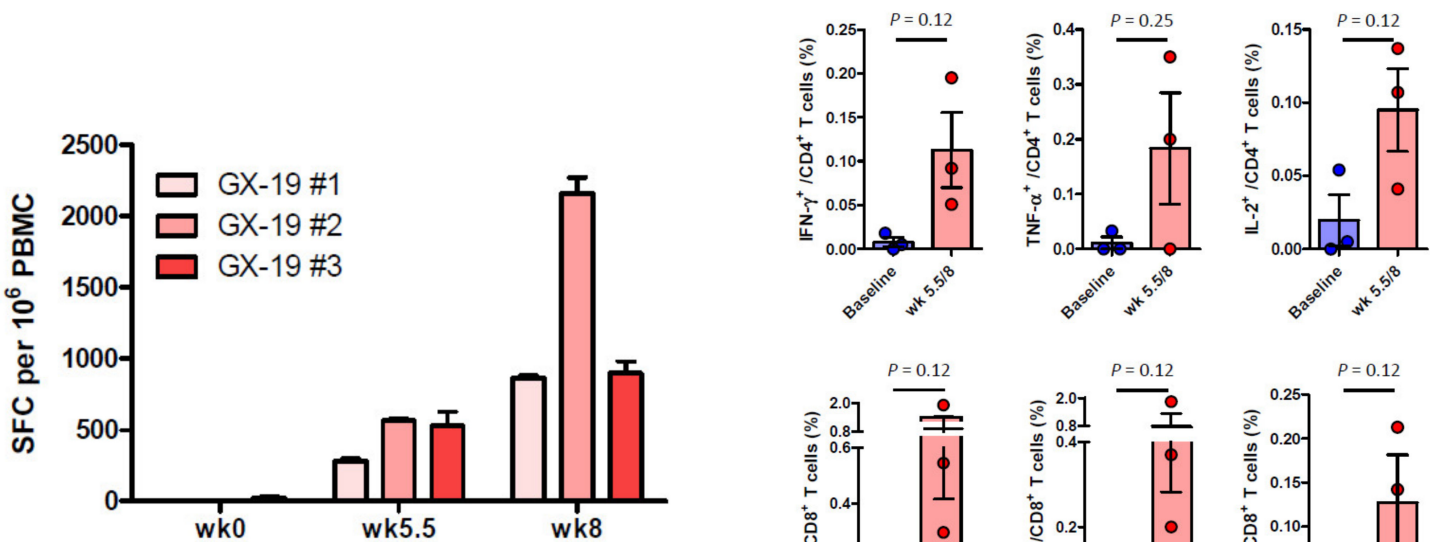

(c)
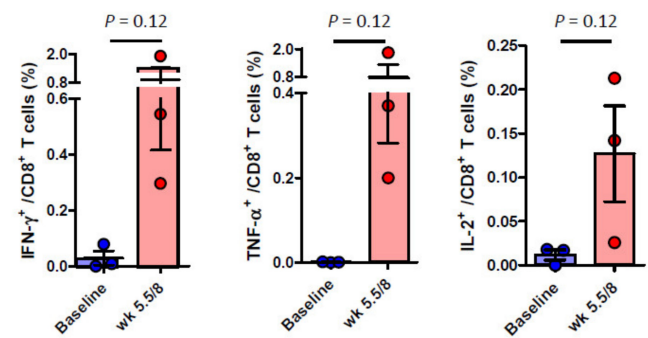

(d)

Figure 4. Antibody and T cell responses after GX-19 vaccination in macaques. Macaques $(n=3)$ were immunized with $3 \mathrm{mg}$ of GX-19 as described in the Methods. Serum and PBMCs (peripheral blood mononuclear cells) were collected before (week 0), during (week 4 and 5.5), and after (week 8) vaccination and were assessed for SARS-CoV-2 S-specific IgG antibodies by ELISA (a) and neutralizing antibodies against SARS-CoV-2 live virus (b). Data represent mean SEM of individual macaques (GX-19 \#1, GX-19 \#2, GX-19 \#3), and dashed line indicates the assay limits of detection. The number of SARS-CoV-2 S-specific IFN- $\gamma$-secreting cells in PBMCs was determined by IFN- $\gamma$ ELISPOT assay after stimulation with peptide pools spanning the SARS-CoV-2 S protein. Shown are spot-forming cells (SFC) per $10^{6}$ PBMCS in triplicate wells (c). The frequency of S-specific $\mathrm{CD}^{+}$or $\mathrm{CD}^{+}{ }^{+} \mathrm{T}$ cells producing IFN- $\gamma$, TNF- $\alpha$, or IL-2 was determined by intracellular cytokine staining assays stimulated with SARS-CoV-2 S peptide pools. Shown are the frequency of S-specific CD4 ${ }^{+}$or CD8 ${ }^{+}$ T cells after subtraction of background (DMSO vehicle) $(\mathbf{d})$. Data of $(\mathbf{a}, \mathbf{b}, \mathbf{d})$ are represented as individual values. $p$-Values determined by the Wilcoxon matched-pairs signed rank test; $p$-values are shown. 
To determine the impact of GX-19 on cellular immune responses, ELISPOT analysis was used to measure $T$ cell responses in the blood of the vaccinated macaques. Three macaques developed $T$ cell responses after single immunization. In addition, all animals exhibited such elevated responses after boost vaccination, implicating that vaccine-induced cellular immune responses became progressively stronger in macaques during GX-19 vaccination (Figure 4c). To gain further insights into GX-19-induced T cell responses, we again measured the frequency of T cells secreting multiple cytokines by ICS. GX-19 vaccination exhibited a meaningful induction of S-specific $\mathrm{CD}^{+}{ }^{+} \mathrm{T}$ cells and $\mathrm{CD} 8^{+} \mathrm{T}$ cells producing IFN- $\gamma$, TNF- $\alpha$, and, to a lesser extent, IL-2 (Figure $4 d$; Supplementary Figure S2).

\subsection{GX-19 Provides Protective Benefits to NHPs from Wild-Type SARS-CoV-2 Infection}

Induction of long-term immunological memory for $\mathrm{T}$ cell and $\mathrm{B}$ cell responses is important for effective vaccine development. Unlike other vaccine studies in which NHPs confirmed protective efficacy against SARS-CoV-2 infection at $4 \sim 6$ weeks after the last vaccination [9,10,27-29], we evaluated the protective efficacy approximately 10 weeks after the last vaccination. Accordingly, macaques were challenged by multiple routes with a total dose of $2.6 \times 10^{7} 50 \%$ tissue culture infectious doses (TCID 50 ), at 10 weeks after the last vaccination. This challenge route and dose were determined based on a model development study in which we challenged macaques that had no previous exposure to the virus [30]. Two of the three naive macaques showed elevated body temperature after viral infection, while none of the GX-19-vaccinated animals exhibited such symptoms. Further, GX-I9-vaccinated macaques showed more rapid recovery from lymphocyte reduction than did unvaccinated counterparts (Supplementary Figure S3a,b). High levels of viral load were observed in the unvaccinated macaques (Figure $5 a, b$ ) with a median peak of 7.54 (range 6.66-8.01) $\log _{10}$ viral copies $/ \mathrm{mL}$ in the nasal swab and a median peak of 6.18 (range 6.01-6.81) $\log _{10}$ viral copies $/ \mathrm{mL}$ in the throat swab (Figure 5c,d). Contrarily, we detected lower levels of viral load in GX-19-vaccinated macaques, including 1.58 and $1.57 \log _{10}$ reductions in the median peak viral load in the nasal swab and throat swab, respectively (Figure 5a-d). Since the peak viral load does not reflect the presence of total virus over time, the virus load was then calculated based on the area under the curve (AUC). GX-19-vaccinated macaques had a viral AUC of $6.02 \pm 0.23 \log _{10}$ in the nasal swab and $4.99 \pm 0.45 \log _{10}$ in the throat swab, respectively, showing 1.46 and $1.45 \log _{10}$ decreases in the viral AUC compared to those from unvaccinated counterparts (Figure 5e,f). For the assessment of infectious viruses, TCID $_{50}$ assay was performed for the nasopharyngeal swab and oropharyngeal swab samples on Vero cells. The infectious viral load showed similar patterns to the viral RNA load. Although the difference was not found to be statistically significant due to the insufficient number of animals, lower levels of infectious viral load were observed in GX-19-vaccinated macaques (Supplementary Figure S3c,d).

At 4 days post-virus inoculation, all animals were euthanized, and tissues were collected. Consistent with previous reports [30], SARS-CoV-2 infection caused moderate to severe inflammation, as evidenced by small airways and adjacent alveolar interstitia in non-vaccinated macaques. In vaccinated macaques, the viral challenge caused mild histopathologic changes compared to those in control macaques (Figure 5g). Further pathological examination of each lung lobe of the challenged macaques also revealed the improvement in the severity of interstitial pneumonia in GX-19-vaccinated macaques (Figure 5h). 


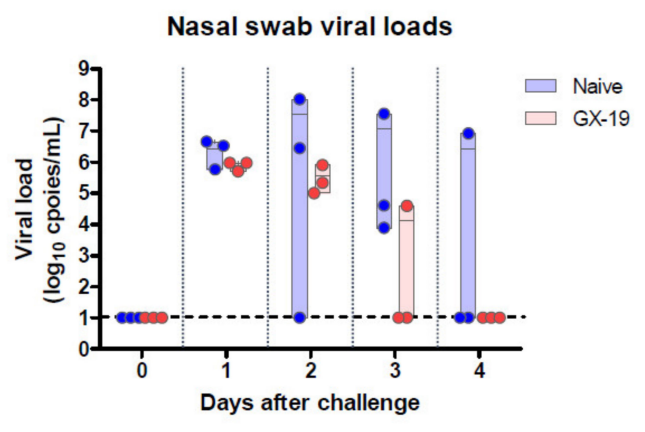

(a)

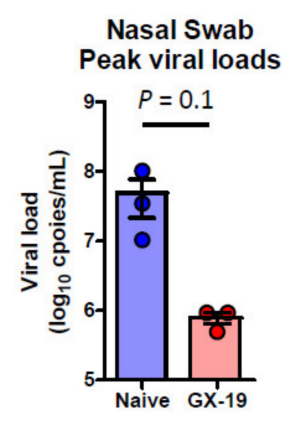

(c)

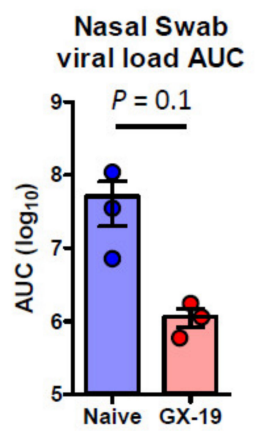

(e)

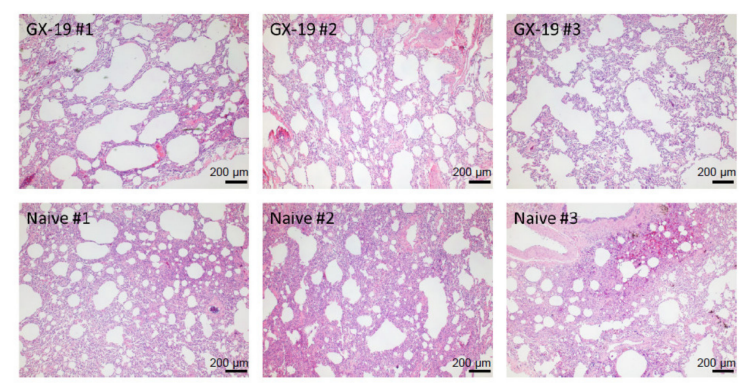

(g)

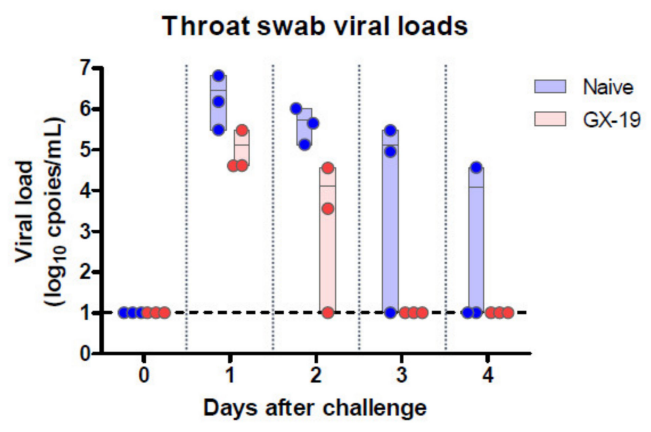

(b)

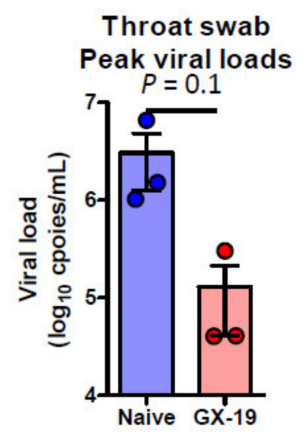

(d)

Throat swab viral load AUC

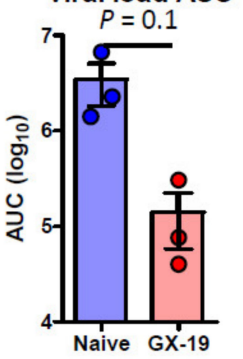

(f)

Interstitial pneumonia

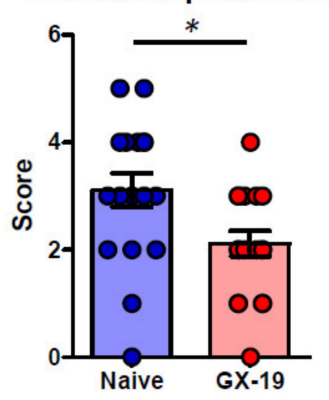

(h)

Figure 5. Protective efficacy of GX-19 against SARS-CoV-2 challenge. Non-vaccinated ( $n=3$, blue) and GX-19-vaccinated macaques $(n=3$, red) were challenged by intratracheal, oral, conjunctival, intranasal, and intravenous administration of $2.7 \times 10^{7} \mathrm{TCID}_{50}$ SARS-CoV-2. Viral load was assessed in nasal swab (a) and throat swab (b) at multiple time points following challenge. Summary of peak viral loads and viral load area under the curve (AUC) in nasal swab (c,e) and throat swab (d,f) following challenge. Dashed line indicates the assay limit of detection. Histopathological changes in the lungs of SARS-CoV-2-challenged macaques (g). Interstitial pneumonia score by microscopic evaluation ( $n=6$ lung lobes of each animal per group) (h). The lung tissue sections were stained with hematoxylin and eosin (H\&E). Data of (a-f) are represented as individual values. Data of $(h)$ is represented as 6 lung lobes of each animal per group. $p$-Values determined by the Mann-Whitney test; $p$-values are shown * $p<0.05$ as determined by the Mann-Whitney test. 


\section{Discussion}

In this study, we demonstrated that GX-19 (pGX27-S $\left.{ }_{\triangle \mathrm{TM}}\right)$ exhibited a higher S-specific antibody response than pGX27-S. In addition, GX-19 could elicit SARS-CoV-2 S-specific Th1-biased T cell responses in mice and NHPs. Vaccination of GX-19 also conferred effective protection against SARS-CoV-2 challenge at 10 weeks following the last vaccination.

The low immunogenicity and protective efficacy of $\mathrm{S}_{\Delta \mathrm{TM}}$ were reported in a recent study on the evaluation of the protective efficacy of a DNA vaccine expressing various forms of the SARS-CoV-2 S protein [9]. Our results also show that, in contrast to the full-length S DNA, GX-19 not only induced high antibody responses in mice and NHPs but also showed effective protection against SARS-CoV-2 virus challenge in NHPs. In the previous study [9], the vaccines were administered without the EP method, the method that significantly enhanced the in vivo delivery efficacy of a DNA vaccine by 100-1000fold [31], resulting in weak antibody responses or T cell responses. On the other hand, electroporation-enhanced GX-19 induced robust antibody and T cell responses. In addition, the extent of increase in the immune response depends on the efficiency of gene expression by the vector [32], and the pGX27 vector has about three times higher expression strength than the commercial vector (unpublished data). Here, we believe that the introduction of a high-expression vector [22] into GX-19 along with an effective EP delivery system resulted in the efficient protective effect against SARS-CoV-2 infection through the induction of strong immune responses. However, further studies will be needed to compare pGX27-S

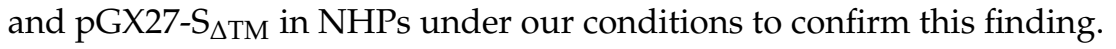

In this study, we observed that GX-19 induced concurrent antibody, $\mathrm{CD}^{+} \mathrm{T}$ cell, and $\mathrm{CD}^{+} \mathrm{T}$ cell responses in both mice and NHP models. Indeed, successful DNA vaccination effectively induces complete complementation of the immune responses, including humoral and cellular responses (CD8 ${ }^{+}$and Th1 cellular responses), similar to those achieved by live attenuated viruses $[15,16,33,34]$. This can be explained by the nature of the DNA vaccine, presumably because its mechanism of action involves both class I antigen-processing pathways (i.e., intracellular processing of viral proteins into peptides and subsequent loading onto MHC class I molecules) and class II antigen-processing pathways (i.e., specifically engineered in the $S$ signal sequence that cause an increased export of viral surface antigens). Among $\mathrm{T}$ cell responses, the balanced Th1/Th2 responses are important because vaccineassociated enhanced respiratory disease (VAERD) is associated with Th2-biased immune responses. Indeed, immunopathologic complications characterized by Th2-biased immune responses have been reported in the animal models of the SARS-CoV and MERS-CoV challenge [23,35-39], and similar phenomena have been reported in clinics vaccinated with whole-inactivated virus vaccines against RSV and measles virus [40,41]. In addition, the importance of $\mathrm{T}$ cell responses has been highlighted by a recent study of asymptomatic and mild SARS-CoV-2 convalescence [42]. These results collectively suggest that vaccines capable of generating balanced antibody responses and $\mathrm{T}$ cell responses may be important in providing protection against SARS-CoV-2 diseases. Here, we show that GX-19 induces Th1-biased responses, suggesting DNA vaccination can avoid the Th2-biased immune response associated with VAERD. In fact, there were subtle pathologic changes in the SARS-CoV-2-infected GX-19 vaccine group. These results were also demonstrated in other respiratory infection DNA vaccines such as for SARS-CoV and MERS-CoV in [43], and MERS-CoV in [33]. This suggests that a DNA vaccine platform can be a good alternative in vaccine development for emerging infections where balanced $\mathrm{T}$ cell and antibody responses are important.

It is desirable that the SARS-CoV-2 vaccine can prevent infection or disease and induce long-term immunity. Virus-specific $\mathrm{T}$ cell responses play an important role in antiviral and disease control. Immune-modulatory cytokines (e.g., IFN- $\gamma$, TNF- $\alpha$, and IL-2) released from virus-specific $\mathrm{CD}^{+} \mathrm{T}$ and $\mathrm{CD} 8^{+} \mathrm{T}$ cells play a key role in several antiviral responses and act in synergy with type I IFNs to inhibit viral replication [44,45]. Patients with impaired IFN- $\gamma$ activity were reported to have 5-fold increased susceptibility to SARS [46]. Clinical cases of asymptomatic virus infection indicate that virus-specific $\mathrm{T}$ cells can control disease even in 
the absence of neutralizing antibodies [42,47]. Here, we show that GX-19 induces potent antigen-specific $\mathrm{CD} 4^{+}$and $\mathrm{CD} 8^{+} \mathrm{T}$ cell activation and robust release of immune-modulatory cytokines in mice and NHPs, indicating that GX-19 can effectively control the disease of SARS-CoV-2. Therefore, clinical cases in which antibody responses rapidly decrease and disappear after SARS-CoV-2 infection indicate the importance of vaccines that can induce long-term immunological memory [48-50]. GX-19 induced potent $\mathrm{CD} 4^{+}$and $\mathrm{CD} 8^{+} \mathrm{T}$ cells in both animal models and it may confer long-lasting immunity against coronaviruses as indicated in SARS survivors, where $\mathrm{CD} 8^{+} \mathrm{T}$ cell immunity persisted up to 11 years [44,51]. We observed the protective benefits against viral infection about 10 weeks after the last vaccination, along with an elevated antibody response 8 weeks after the last vaccination. This indicates that the GX-19-induced immune response is long-lasting and also provides protective benefits against viral infection. Lastly, in the previous reports of NHP infection of other vaccines, the viral loads were almost completely controlled by vaccination at the beginning of the infection [29,52] and mild histopathological changes were observed [27,52]. Similar to the previous reports, our results also show mild histopathological changes compared to the control NHPs. Unlike previous reports, however, our results do not provide complete virus control at the beginning of the infection. This difference can be explained by the difference in the viral challenge doses and the difference in the time of viral challenge after the last vaccination. NHPs were challenged with higher viral doses $\left(2.6 \times 10^{7} \mathrm{TCID}_{50}\right)$ than previous reports $\left(2 \times 10^{4} \sim 4 \times 10^{5} \mathrm{TCID}_{50}\right)$ and had a longer period (10 weeks) from last vaccination to viral infection compared to previous reports (4 6 weeks). However, these conclusions are drawn from a limited number of animals, especially in NHP models, so there is a limit to making clear conclusions. Additional studies involving a greater number of subjects will be needed to assess the safety and durability of the immune response and to assess protection against viral infection.

One drawback of this study was that it did not show statistical significance between naïve and GX-19-vaccinated NHPs due to the small number of NHPs. In fact, as a result of post hoc analysis on the results of NHP viral infection, the post hoc power values of viral loads of nasal swabs and throat swabs were found to be about $0.40 \sim 0.56$. Based on the results, we calculated the number of animals per group that can guarantee more than $80 \%$ power, and as a result, it was expected that statistical significance could be secured if the experiments were conducted with at least five subjects per group.

\section{Methods}

DNA vaccine construction. The SARS-CoV-2 DNA construct encodes the SARS-CoV2 spike (S) protein sequence of the current reported sequence (GenBank: QHD43416.1) as in other research cases $[9,29]$. The vaccine insert was codon optimized and commercially synthesized (Thermo Fisher Scientific, Carlsbad, CA, USA). Synthetic genes were subcloned into high-expression vector pGX27 [22].

Mouse immunizations. Female BALB/c mice aged 6-8 weeks (Koatech, Pyeongtaeksk, Gyeonggi-do, Republic of Korea) were immunized with GX-19 vaccine or pGX27 in a total volume of $50 \mu \mathrm{L}$ of PBS into the tibialis anterior muscle with in vivo electroporation with OrbiJector ${ }^{\circledR}$ (SL VAXiGEN Inc, Seongnam-si, Gyeonggi-do, Republic of Korea) at weeks 0 and 2. On days 14 and 28, blood or BAL (bronchoalveolar lavage) fluid was collected, and mice were sacrificed 14 days after final immunization.

NHP immunizations and challenge. Cynomolgus macaques that weighed between 3.4 and $4.4 \mathrm{~kg}$ and had a mean age of 5.6 years (age range, 4.1-7.6 years) were immunized with $3 \mathrm{mg}$ GX-19 vaccine at week 0 , week 3, and week 5.5. GX-19 vaccine was given intramuscularly, followed by electroporation using OrbiJector ${ }^{\circledR}$ (SL VAXiGEN Inc.). Blood was collected immediately before the first immunization (week 0 ) and every 1-3 weeks thereafter through week 8 , and sera and PBMCs (peripheral blood mononuclear cells) were isolated to evaluate the humoral or cellular immune responses, respectively. At 10 weeks after the last vaccination, immunized macaques were moved to the animal biosecurity level 3 (ABL-3) laboratory in the Korea National Primate Research Centre (KNPRC) at 
the Korea Research Institute of Bioscience and Biotechnology (KRIBB). All animals were challenged with total $2.6 \times 10^{7} 50 \%$ tissue culture infectious doses $/ \mathrm{mL}\left[\mathrm{TCID}_{50}\right] / \mathrm{mL}$ SARS-CoV-2 virus, obtained from the National Culture Collection for Pathogens (accession number 43326), via combined routes (intratracheal $(4 \mathrm{~mL})$, oral $(5 \mathrm{~mL})$, conjunctival $(0.5 \mathrm{~mL})$, intranasal $(1 \mathrm{~mL})$, and intravenous route $(2 \mathrm{~mL}))$ as previously described [30]. After viral challenge, macaques were anesthetized with ketamine sodium $(10 \mathrm{mg} / \mathrm{kg})$ and tiletamine/zolazepam ( $5 \mathrm{mg} / \mathrm{kg}$ ) for temperature measurement and sample collection. Blood, nasopharyngeal swabs, and oropharyngeal swabs were collected at $0,1,2,3$, and 4 days post-infection (dpi). Swab samples were centrifuged at $1600 \times g$ for $10 \mathrm{~min}$ and filtered with $0.2 \mu \mathrm{m}$ pore size syringe filters for further virus quantification. Immunization procedures were approved by the Institutional Animal Care and Use Committee (IACUC permit number ORIENT-IACUC-20044), and challenging procedures were approved by KRIBB IACUC (permit number KRIBB-AEC-20178).

Antigen binding ELISA. Serum and BAL fluid collected at each time point were evaluated for binding titers. Ninety-six-well immunosorbent plates (NUNC) were coated with $1 \mu \mathrm{g} / \mathrm{mL}$ recombinant SARS-CoV-2 S1+S2 ECD protein (Sino Biological 40589-V08B1) and S1 protein (Sino Biological 40591-V08H) in PBS (phosphate-buffered saline) overnight at $4{ }^{\circ} \mathrm{C}$. Plates were washed 3 times with $0.05 \%$ PBST (Tween 20 in PBS) and blocked with $5 \%$ skim milk in $0.05 \%$ PBST (SM) for $2-3 \mathrm{~h}$ at room temperature. Sera or BAL fluid were serially diluted in 5\% SM, added to the wells, and incubated for $2 \mathrm{~h}$ at $37^{\circ} \mathrm{C}$. Following incubation, plates were washed 5 times with $0.05 \%$ PBST and then incubated with horseradish peroxidase (HRP)-conjugated anti-mouse IgG (Jackson ImmunoResearch Laboratories 115-035-003, West Grove, PA, USA), IgG1 (Jackson ImmunoResearch Laboratories 115-035-205, West Grove, PA, USA), IgG2a (Jackson ImmunoResearch Laboratories 115-035-206, West Grove, PA, USA), or IgG2b (Jackson ImmunoResearch Laboratories 115-035-207, West Grove, PA, USA) for the mouse sera/BAL or anti-monkey IgG (Bethyl Laborabories A140-102P, Montgomery, AL, USA) for the NHP sera for $1 \mathrm{~h}$ at $37^{\circ} \mathrm{C}$. After final wash, plates were developed using TMB solution (Surmodics TMBW-0100-01, Eden Prairie, MN, USA) and the reaction was stopped with $2 \mathrm{~N} \mathrm{H}_{2} \mathrm{SO}_{4}$. The plates were read at $450 \mathrm{~nm}$ by SpectraMax Plus384 (Molecular Devices, San Jose, CA, USA).

Live virus neutralization assay. Vero cells $\left(1.5 \times 10^{4}\right.$ cells/well $)$ were seeded on a 96-well plate (Nunc, 167008) and incubated at $37{ }^{\circ} \mathrm{C}$ and $5 \% \mathrm{CO}_{2}$ for $16 \mathrm{~h}$. Serum samples were inactivated via incubation at $56{ }^{\circ} \mathrm{C}$ for $30 \mathrm{~min}$ and mixed with SARS-CoV-2 (300 plaque forming unit/25 $\mu \mathrm{L}$ ) and incubated at $37{ }^{\circ} \mathrm{C}$ and $5 \% \mathrm{CO}_{2}$ for $30 \mathrm{~min}$. The serum-virus mixture was treated on the Vero cells and incubated at $37^{\circ} \mathrm{C}$ and $5 \% \mathrm{CO}_{2}$ for $4 \mathrm{~h}$. After incubation, the treated mixture was removed and the cells were washed using $100 \mu \mathrm{L}$ of phosphate buffered saline (PBS) (Gibco, 10010-023, Carlbad, CA, USA). The Vero cells were fixed using $300 \mu \mathrm{L}$ of $10 \%$ formalin solution (Sigma, F8775, St.Louis, MO, USA) by incubating at $4{ }^{\circ} \mathrm{C}$ for overnight. After washing, the Vero cells were permeabilized by adding $100 \mu \mathrm{L}$ of ice-cold 100\% methanol (Sigma, D7, St.Louis, MO, USA). After 10 min incubation at room-temperature, the methanol was removed and the Vero cells were washed using $100 \mu \mathrm{L}$ PBS, blocked using $100 \mu \mathrm{L}$ of blocking buffer $(0.5 \%$ normal goat serum (Abcam, Ab7481, Cambridge, CB2 0AX, UK) + 0.1\% Tween 20 (GenDEPOT, T9100100, Houston, TX, USA) + 1\% (w/v) Bovine serum albumin (Sigma, 803-100G, St.Louis, $\mathrm{MO}, \mathrm{USA}$ ) in PBS) and incubated at room temperature for $30 \mathrm{~min}$ incubation at room temperature. After removing the blocking buffer, 3000-fold diluted $100 \mu \mathrm{L}$ of anti-SARSCoV-2 NP rabbit mAb (Sino Biological, 40143-R001, Beijing, China) was added on the Vero cells and incubated at $37^{\circ} \mathrm{C}$ for $1 \mathrm{~h}$. After removing the Ab solution on the Vero cells, the Vero cells were washed using $200 \mu \mathrm{L}$ of PBS containing $0.1 \%$ Tween 20. 2000-fold diluted goat anti-rabbit IgG-HRP (Bio-Rad, 170-6515, Hercules, CA, USA) solution was treated on the Vero cells and incubated at $37^{\circ} \mathrm{C}$ for $1 \mathrm{~h}$. After removing the goat anti-rabbit IgG-HRP solution, the Vero cells were washed using $200 \mu \mathrm{L}$ of PNS containing $0.1 \%$ Tween $20.30 \mu \mathrm{L}$ of TrueBlue solution was added on the Vero cells and incubate at room temperature for 30 min. After removing the TrueBlue solution, the cells were air dried until completely dry. 
The numbers of focus of each well were read using CTL reader (Cellular Technology Ltd., Shaker Heights, $\mathrm{OH}$ ) and the neutralizing Ab titers were calculated using Microsoft Excel and SoftMax (Version 5.4.1) (Molecular Devices, San Jose, CA, USA).

IFN- $\gamma$ ELISPOT. For mouse samples, the Mouse IFN- $\gamma$ ELISPOT set (BD 551083) was used as directed by the manufacturer. ELISPOT plates were coated with purified anti-mouse IFN- $\gamma$ capture antibody and incubated overnight at $4{ }^{\circ} \mathrm{C}$. Plates were washed and blocked for $2 \mathrm{~h}$ with RPMI $+10 \%$ FBS (R10 media, Hyclone, St.Louis, MO, USA). Five hundred thousand splenocytes were added to each well and stimulated for $24 \mathrm{~h}$ at $37^{\circ} \mathrm{C}$ in $5 \% \mathrm{CO}_{2}$ with R10 media (negative control), concanavalin A (positive control), or specific peptide antigens $(2 \mu \mathrm{g} / \mathrm{mL})$. Peptide pools consisted of 15 -mer peptides overlapped by 11 amino acids and spanned the entire SARS-CoV-2 S protein (GenScript, Nanjing, China). After stimulation, the plates were washed and spots were developed according to the manufacturer's instructions. For NHP samples, the Monkey IFN- $\gamma$ ELISpot ${ }^{\text {PLUS }}$ kit (MABTECH 3421M-APT-10) was used as directed by the manufacturer. Two hundred thousand PBMCs were stimulated with peptide pools, and plates were washed and spots were developed according to the manufacturer's instructions. Plates were scanned and counted on AID ELISPOT reader classic. Spot-forming unit (SFU) per million cells was calculated by subtracting the negative control wells.

Intracellular cytokine staining. For mouse samples, splenocytes were stimulated in R10 media with specific peptide pools or medium alone (DMSO control) for $12 \mathrm{~h}$. After stimulation, cells were washed with PBS for subsequent immunostaining. Antibodies for staining cells were CD8 FITC (Biolegend 100706, San Diego, CA, USA), IL-2 PE (Biolegend 503808), CD4 PE-Cy7 (Biolegend 100528), IFN- $\gamma$ APC (Biolegend 505810), TNF- $\alpha$ (Biolegend 506328), CD3 BV605 (Biolgend 100351), and Live/dead IR (Invitrogen L10119). For NHP samples, cryopreserved and thawed PBMCs were resuspended in R10 media and rested overnight at $37^{\circ} \mathrm{C}, 5 \% \mathrm{CO}_{2}$, and subsequently PBMCs were stimulated in R10 media with specific peptide pools or medium alone (DMSO control) in the presence of $1 \mu \mathrm{g} / \mathrm{mL}$ of $\alpha$-CD28 (BD bioscience 555725) and $\alpha$-CD49d (BD bioscience 555501, San Jose, CA, USA) for $12 \mathrm{~h}$. After stimulation, cells were washed with PBS for subsequent immunostaining and polychromatic flowy cytometric analysis. Antibodies for staining cells were CD3 PE (BD bioscience 552127), CD4 PerCP-Cy5.5 (Biolegend 317428), CD8a PE-Cy7 (Biolegend 301012), IFN- $\gamma$ APC (Biolegend 506510), TNF- $\alpha$ BV421 (Biolegend 502932), IL-2 BV605 (Biolegend 500332), and Live/dead Near-IR (Invitrogen L10119). Fluorescence-activated cell sorting analysis was accomplished by a Fortessa flow cytometer (BD bioscience), and the data were analyzed using FlowJo software. Background cytokine expression in the DMSO controls was subtracted from that measured in the $S$ peptide pools.

Cytokine profile analysis by cytometric bead array (CBA). Five hundred thousand splenocytes were plated and stimulated in R10 media with peptide pools (15-mers with 11mer overlaps) corresponding to the SARS-CoV-2 S proteins $(2 \mu \mathrm{g} / \mathrm{mL})$ or the medium only as negative control in 96-well plates. Culture supernatants were harvested $48 \mathrm{~h}$ after the stimulation and cytokines were quantitated by the $\mathrm{BD}^{\mathrm{TM}} \mathrm{CBA}$ Mouse Th1/Th2 Cytokine kit (BD Biosciences) according to manufacturer's instructions.

Virus identification and quantification. Filtered swab samples were inoculated into Vero cells and incubated for 3 days at $37^{\circ} \mathrm{C}$, for virus isolation to calculate the values of TCID50/mL using the Reed and Muench method. The viral RNA genome was extracted from the supernatant using QIAamp Viral RNA mini Kit (Qiagen, Germantown, MD, USA) and stored at $-80^{\circ} \mathrm{C}$ in the ABL-3 facility until use. RT-qPCR was performed with a primer set targeting partial regions of the ORF1b gene in the SARS-CoV-2 virus using the QIAGEN OneStep RT-PCR kit (Qiagen) as previously reported [53]. For all RT-qPCR analyses, SARSCoV-2 RNA standard and negative samples were run in parallel for determination of virus copy number.

Histological evaluation. Six lobes of the lung samples (three lobes in the right and the left lung, namely upper, middle, and lower lobes) of infected macaques were fixed in $4 \%$ paraformaldehyde for a minimum of 7 days and embedded in paraffin, and 4- to $5-\mu \mathrm{m}$ 
sections were stained with hematoxylin and eosin. Sections of lung were blindly examined microscopically and given a score for severity of interstitial pneumonia from 0 (normal) to 6 (severe diffuse interstitial pneumonia).

Statistical analysis. Analysis of virologic and immunologic data was performed using GraphPad Prism 5 (GraphPad Software, San Diego, CA, USA). Comparison of data between groups was performed using two-sided Mann-Whitney tests. $p$-Values $<0.05$ were considered significant. Post hoc power analysis was performed on results of the NHPs viral infection, and viral loads of nasal swab and throat swab were used as evaluation variables. Post hoc power analysis was based on Mann-Whitney tests using PASS2020 (NCSS Statistical Software, Kaysville, UT, USA).

\section{Conlusions}

In summary, these results explain the promising immunogenicity of GX-19 and, in particular, support the clinical potential of GX-19 by showing the protective effect against infection from NHPs.

Supplementary Materials: The following are available online at https://www.mdpi.com/2076-3 93X/9/4/307/s1, Figure S1: Flow cytometry panel to quantify SARS-CoV-2 S-specific mouse CD4+ or CD8+ T cells, Figure S2: Flow cytometry panel to quantify SARS-CoV-2 S-specific NHP CD4+ or CD8+ T cells, Figure S3: Clinical signs and TCID50/mL in macaques challenged with SARS-CoV-2 after vaccination with GX-19.

Author Contributions: Y.B.S. contributed to study design, oversaw the planning of the project, analyzed the data, and wrote the manuscript. Y.S.S. contributed to study coordination, oversaw the planning of the project. J.I.R. and H.J. performed experiments and data analysis, including sample processing, ELISA, and IFN- $\gamma$ ELISPOT assays. H.O., B.-S.K., and J.J.H. designed and analyzed NHP viral infection assays. S.-H.S. and M.S. designed and analyzed the neutralization assays. S.-J.K. coordinated NHP samples processing and distribution. Y.C.S. oversaw the planning and direction of the project including analysis and interpretation of the data and editing of the manuscript. All authors have read and agreed to the published version of the manuscript.

Funding: This Work was supported by Korea Research Institute of Bioscience and Biotechnology (grant number KGM4572121) and ministry of Science and ICS (grand number PRM1752011).

Institutional Review Board Statement: Immunization procedures were approved by the Institutional Animal Care and Use Committee (IACUC permit number ORIENT-IACUC-20044), and challenging procedures were approved by KRIBB IACUC (permit number KRIBB-AEC-20178).

Informed Consent Statement: Not applicable.

Data Availability Statement: The data that support the findings of this study are available from the corresponding authors upon request.

Acknowledgments: The pathogen resources (NCCP43326) for this study were provided by the National Culture Collection for Pathogens.

Conflicts of Interest: Y.B.S., J.I.R., and H.J. are employees of SL VaxiGen Inc. Y.S.S. and Y.C.S are employees of Genexine Inc. Y.C.S serves as Scientific Advisor for SL VaxiGen. S.K is an employee of GenNbio Inc. The remaining authors declare no competing interests.

\section{References}

1. Wu, F.; Zhao, S.; Yu, B.; Chen, Y.M.; Wang, W.; Song, Z.G.; Hu, Y.; Tao, Z.W.; Tian, J.H.; Pei, Y.Y.; et al. A new coronavirus associated with human respiratory disease in China. Nature 2020, 579, 265-269. [CrossRef] [PubMed]

2. Huang, C.; Wang, Y.; Li, X.; Ren, L.; Zhao, J.; Hu, Y.; Zhang, L.; Fan, G.; Xu, J.; Gu, X.; et al. Clinical features of patients infected with 2019 novel coronavirus in Wuhan, China. Lancet 2020, 395, 497-506. [CrossRef]

3. Center for Systems Science and Engineering (CSSE) at Johns Hopkins University (JHU). COVID-19 Dashboard. Available online: https:/ / gisanddata.maps.arcgis.com/apps/opsdashboard/index.html\#/bda7594740fd40299423467b48e9ecf6 (accessed on 5 August 2020).

4. Graham, B.S. Rapid COVID-19 vaccine development. Science 2020, 368, 945-946. [CrossRef]

5. Bonam, S.R.; Kotla, N.G.; Bohara, R.A.; Rochev, Y.; Webster, T.J.; Bayry, J. Potential immuno-nanomedicine strategies to fight COVID-19 like pulmonary infections. Nano Today 2021, 36, 101051. [CrossRef] 
6. Shin, M.D.; Shukla, S.; Chung, Y.H.; Beiss, V.; Chan, S.K.; Ortega-Rivera, O.A.; Wirth, D.M.; Chen, A.; Sack, M.; Pokorski, J.K.; et al. COVID-19 vaccine development and a potential nanomaterial path forward. Nat. Nanotechnol. 2020, 15, 646-655. [CrossRef]

7. Benvenuto, D.; Giovanetti, M.; Ciccozzi, A.; Spoto, S.; Angeletti, S.; Ciccozzi, M. The 2019-new coronavirus epidemic: Evidence for virus evolution. J. Med. Virol. 2020, 92, 455-459. [CrossRef]

8. Corbett, K.S.; Edwards, D.K.; Leist, S.R.; Abiona, O.M.; Boyoglu-Barnum, S.; Gillespie, R.A.; Himansu, S.; Schafer, A.; Ziwawo, C.T.; DiPiazza, A.T.; et al. SARS-CoV-2 mRNA vaccine design enabled by prototype pathogen preparedness. Nature 2020, 586, 567-571. [CrossRef] [PubMed]

9. Yu, J.; Tostanoski, L.H.; Peter, L.; Mercado, N.B.; McMahan, K.; Mahrokhian, S.H.; Nkolola, J.P.; Liu, J.; Li, Z.; Chandrashekar, A.; et al. DNA vaccine protection against SARS-CoV-2 in rhesus macaques. Science 2020, 369, 806-811. [CrossRef]

10. Corbett, K.S.; Flynn, B.; Foulds, K.E.; Francica, J.R.; Boyoglu-Barnum, S.; Werner, A.P.; Flach, B.; O'Connell, S.; Bock, K.W.; minai, M.; et al. Evaluation of the mRNA-1273 Vaccine against SARS-CoV-2 in Nonhuman Primates. N. Engl. J. Med. 2020, 383, 1544-1555. [CrossRef] [PubMed]

11. World Health Organization. Draft landscape of COVID-19 Candidate Vaccines. Available online: https://www.who.int/ publications/m/item/draft-landscape-of-covid-19-candidate-vaccines (accessed on 25 August 2020).

12. Graham, B.S.; Mascola, J.R.; Fauci, A.S. Novel Vaccine Technologies: Essential Components of an Adequate Response to Emerging Viral Diseases. JAMA 2018, 319, 1431-1432. [CrossRef] [PubMed]

13. Dowd, K.A.; Ko, S.Y.; Morabito, K.M.; Yang, E.S.; Pelc, R.S.; DeMaso, C.R.; Castilho, L.R.; Abbink, P.; Boyd, M.; Nityanandam, R.; et al. Rapid development of a DNA vaccine for Zika virus. Science 2016, 354, 237-240. [CrossRef] [PubMed]

14. Kutzler, M.A.; Weiner, D.B. DNA vaccines: Ready for prime time? Nat. Rev. Genet. 2008, 9, 776-788. [CrossRef] [PubMed]

15. Modjarrad, K.; Roberts, C.C.; Mills, K.T.; Castellano, A.R.; Paolino, K.; Muthumani, K.; Reuschel, E.L.; Robb, M.L.; Racine, T.; Oh, M.-d.; et al. Safety and immunogenicity of an anti-Middle East respiratory syndrome coronavirus DNA vaccine: A phase 1, open-label, single-arm, dose-escalation trial. Lancet Infect. Dis. 2019, 19, 1013-1022. [CrossRef]

16. Gaudinski, M.R.; Houser, K.V.; Morabito, K.M.; Hu, Z.; Yamshchikov, G.; Rothwell, R.S.; Berkowitz, N.; Mendoza, F.; Saunders, J.G.; Novik, L.; et al. Safety, tolerability, and immunogenicity of two Zika virus DNA vaccine candidates in healthy adults: Randomised, open-label, phase 1 clinical trials. Lancet 2018, 391, 552-562. [CrossRef]

17. Tebas, P.; Roberts, C.C.; Muthumani, K.; Reuschel, E.L.; Kudchodkar, S.B.; Zaidi, F.I.; White, S.; Khan, A.S.; Racine, T.; Choi, H.; et al. Safety and Immunogenicity of an Anti-Zika Virus DNA Vaccine_Preliminary Report. N. Engl. J. Med. 2017. [CrossRef] [PubMed]

18. Das, M. A promising therapeutic vaccine for cervical precancer. Lancet Oncol. 2019, 20, e671. [CrossRef]

19. Trimble, C.L.; Morrow, M.P.; Kraynyak, K.A.; Shen, X.; Dallas, M.; Yan, J.; Edwards, L.; Parker, R.L.; Denny, L.; Giffear, M.; et al. Safety, efficacy, and immunogenicity of VGX-3100, a therapeutic synthetic DNA vaccine targeting human papillomavirus 16 and 18 E6 and E7 proteins for cervical intraepithelial neoplasia 2/3: A randomised, double-blind, placebo-controlled phase $2 \mathrm{~b}$ trial. Lancet 2015, 386, 2078-2088. [CrossRef]

20. Tiriveedhi, V.; Tucker, N.; Herndon, J.; Li, L.; Sturmoski, M.; Ellis, M.; Ma, C.; Naughton, M.; Lockhart, A.C.; Gao, F.; et al. Safety and preliminary evidence of biologic efficacy of a mammaglobin-a DNA vaccine in patients with stable metastatic breast cancer. Clin. Cancer Res. 2014, 20, 5964-5975. [CrossRef] [PubMed]

21. Tiriveedhi, V.; Fleming, T.P.; Goedegebuure, P.S.; Naughton, M.; Ma, C.; Lockhart, C.; Gao, F.; Gillanders, W.E.; Mohanakumar, T. Mammaglobin-A cDNA vaccination of breast cancer patients induces antigen-specific cytotoxic CD4+ICOShi T cells. Breast Cancer Res. Treat. 2013, 138, 109-118. [CrossRef]

22. Kim, T.J.; Jin, H.T.; Hur, S.Y.; Yang, H.G.; Seo, Y.B.; Hong, S.R.; Lee, C.W.; Kim, S.; Woo, J.W.; Park, K.S.; et al. Clearance of persistent HPV infection and cervical lesion by therapeutic DNA vaccine in CIN3 patients. Nat. Commun. 2014, 5, 5317. [CrossRef] [PubMed]

23. Tseng, C.T.; Sbrana, E.; Iwata-Yoshikawa, N.; Newman, P.C.; Garron, T.; Atmar, R.L.; Peters, C.J.; Couch, R.B. Immunization with SARS coronavirus vaccines leads to pulmonary immunopathology on challenge with the SARS virus. PLoS ONE 2012, 7, e35421. [CrossRef]

24. Honda-Okubo, Y.; Barnard, D.; Ong, C.H.; Peng, B.H.; Tseng, C.T.; Petrovsky, N. Severe acute respiratory syndrome-associated coronavirus vaccines formulated with delta inulin adjuvants provide enhanced protection while ameliorating lung eosinophilic immunopathology. J. Virol. 2015, 89, 2995-3007. [CrossRef] [PubMed]

25. Zhao, J.; Zhao, J.; Perlman, S. T cell responses are required for protection from clinical disease and for virus clearance in severe acute respiratory syndrome coronavirus-infected mice. J. Virol. 2010, 84, 9318-9325. [CrossRef]

26. Mills, C.D.; Kincaid, K.; Alt, J.M.; Heilman, M.J.; Hill, A.M. M-1/M-2 macrophages and the Th1/Th2 paradigm. J. Immunol. 2000, 164, 6166-6173. [CrossRef] [PubMed]

27. Van Doremalen, N.; Lambe, T.; Spencer, A.; Belij-Rammerstorfer, S.; Purushotham, J.N.; Port, J.R.; Avanzato, V.A.; Bushmaker, T.; Flaxman, A.; Ulaszewska, M.; et al. ChAdOx1 nCoV-19 vaccine prevents SARS-CoV-2 pneumonia in rhesus macaques. Nature 2020, 586, 578-582. [CrossRef]

28. Gao, Q.; Bao, L.; Mao, H.; Wang, L.; Xu, K.; Yang, M.; Li, Y.; Zhu, L.; Wang, N.; Lv, Z.; et al. Rapid development of an inactivated vaccine candidate for SARS-CoV-2. Science 2020, 369, 77-81. [CrossRef]

29. Mercado, N.B.; Zahn, R.; Wegmann, F.; Loos, C.; Chandrashekar, A.; Yu, J.; Liu, J.; Peter, L.; McMahan, K.; Tostanoski, L.H.; et al. Single-shot Ad26 vaccine protects against SARS-CoV-2 in rhesus macaques. Nature 2020, 586, 583-588. [CrossRef] 
30. Koo, B.S.; Oh, H.; Kim, G.; Hwang, E.H.; Jung, H.; Lee, Y.; Kang, P.; Park, J.H.; Ryu, C.M.; Hong, J.J. Transient lymphopenia and interstitial pneumonia with endotheliitis in SARS-CoV-2-infected macaques. J. Infect. Dis. 2020, 222, 1596-1600. [CrossRef]

31. Sardesai, N.Y.; Weiner, D.B. Electroporation delivery of DNA vaccines: Prospects for success. Curr. Opin. Immunol. 2011, 23, 421-429. [CrossRef]

32. Lee, A.H.; Suh, Y.S.; Sung, J.H.; Yang, S.H.; Sung, Y.C. Comparison of various expression plasmids for the induction of immune response by DNA immunization. Mol. Cells 1997, 7, 495-501. [PubMed]

33. Muthumani, K.; Falzarano, D.; Reuschel, E.L.; Tingey, C.; Flingai, S.; Villarreal, D.O.; Wise, M.; Patel, A.; Izmirly, A.; Aljuaid, A.; et al. A synthetic consensus anti-spike protein DNA vaccine induces protective immunity against Middle East respiratory syndrome coronavirus in nonhuman primates. Sci. Transl. Med. 2015, 7, 301ra132. [CrossRef]

34. Bagarazzi, M.L.; Yan, J.; Morrow, M.P.; Shen, X.; Parker, R.L.; Lee, J.C.; Giffear, M.; Pankhong, P.; Khan, A.S.; Broderick, K.E.; et al. Immunotherapy against HPV16/18 generates potent TH1 and cytotoxic cellular immune responses. Sci. Transl. Med. 2012, 4, 155ra138. [CrossRef]

35. Iwata-Yoshikawa, N.; Uda, A.; Suzuki, T.; Tsunetsugu-Yokota, Y.; Sato, Y.; Morikawa, S.; Tashiro, M.; Sata, T.; Hasegawa, H.; Nagata, N. Effects of Toll-like receptor stimulation on eosinophilic infiltration in lungs of BALB/c mice immunized with UV-inactivated severe acute respiratory syndrome-related coronavirus vaccine. J. Virol. 2014, 88, 8597-8614. [CrossRef]

36. Bolles, M.; Deming, D.; Long, K.; Agnihothram, S.; Whitmore, A.; Ferris, M.; Funkhouser, W.; Gralinski, L.; Totura, A.; Heise, M.; et al. A double-inactivated severe acute respiratory syndrome coronavirus vaccine provides incomplete protection in mice and induces increased eosinophilic proinflammatory pulmonary response upon challenge. J. Virol. 2011, 85, 12201-12215. [CrossRef] [PubMed]

37. Yasui, F.; Kai, C.; Kitabatake, M.; Inoue, S.; Yoneda, M.; Yokochi, S.; Kase, R.; Sekiguchi, S.; Morita, K.; Hishima, T.; et al. Prior immunization with severe acute respiratory syndrome (SARS)-associated coronavirus (SARS-CoV) nucleocapsid protein causes severe pneumonia in mice infected with SARS-CoV. J. Immunol. 2008, 181, 6337-6348. [CrossRef]

38. Wang, Q.; Zhang, L.; Kuwahara, K.; Li, L.; Liu, Z.; Li, T.; Zhu, H.; Liu, J.; Xu, Y.; Xie, J.; et al. Immunodominant SARS Coronavirus Epitopes in Humans Elicited both Enhancing and Neutralizing Effects on Infection in Non-human Primates. ACS Infect. Dis. 2016, 2, 361-376. [CrossRef] [PubMed]

39. Agrawal, A.S.; Tao, X.; Algaissi, A.; Garron, T.; Narayanan, K.; Peng, B.H.; Couch, R.B.; Tseng, C.T. Immunization with inactivated Middle East Respiratory Syndrome coronavirus vaccine leads to lung immunopathology on challenge with live virus. Hum. Vaccines Immunother. 2016, 12, 2351-2356. [CrossRef] [PubMed]

40. Kim, H.W.; Canchola, J.G.; Brandt, C.D.; Pyles, G.; Chanock, R.M.; Jensen, K.; Parrott, R.H. Respiratory syncytial virus disease in infants despite prior administration of antigenic inactivated vaccine. Am. J. Epidemiol. 1969, 89, 422-434. [CrossRef]

41. Fulginiti, V.A.; Eller, J.J.; Downie, A.W.; Kempe, C.H. Altered reactivity to measles virus. Atypical measles in children previously immunized with inactivated measles virus vaccines. JAMA 1967, 202, 1075-1080. [CrossRef] [PubMed]

42. Sekine, T.; Perez-Potti, A.; Rivera-Ballesteros, O.; Strålin, K.; Gorin, J.-B.; Olsson, A.; Llewellyn-Lacey, S.; Kamal, H.; Bogdanovic, G.; Muschiol, S.; et al. Robust T cell immunity in convalescent individuals with asymptomatic or mild COVID-19. Cell 2020, 183, 158-168.e14. [CrossRef]

43. Yang, Z.Y.; Kong, W.P.; Huang, Y.; Roberts, A.; Murphy, B.R.; Subbarao, K.; Nabel, G.J. A DNA vaccine induces SARS coronavirus neutralization and protective immunity in mice. Nature 2004, 428, 561-564. [CrossRef]

44. Vabret, N.; Britton, G.J.; Gruber, C.; Hegde, S.; Kim, J.; Kuksin, M.; Levantovsky, R.; Malle, L.; Moreira, A.; Park, M.D.; et al. Immunology of COVID-19: Current State of the Science. Immunity 2020, 52, 910-941. [CrossRef]

45. Sainz, B., Jr.; Mossel, E.C.; Peters, C.J.; Garry, R.F. Interferon-beta and interferon-gamma synergistically inhibit the replication of severe acute respiratory syndrome-associated coronavirus (SARS-CoV). Virology 2004, 329, 11-17. [CrossRef]

46. Chong, W.P.; Ip, W.K.; Tso, G.H.; Ng, M.W.; Wong, W.H.; Law, H.K.; Yung, R.W.; Chow, E.Y.; Au, K.L.; Chan, E.Y.; et al. The interferon gamma gene polymorphism $+874 \mathrm{~A} / \mathrm{T}$ is associated with severe acute respiratory syndrome. BMC Infect. Dis. 2006, 6, 82. [CrossRef]

47. Gallais, F.; Velay, A.; Wendling, M.-J.; Nazon, C.; Partisani, M.; Sibilia, J.; Candon, S.; Fafi-Kremer, S. Intrafamilial Exposure to SARS-CoV-2 Induces Cellular Immune Response without Seroconversion. medRxiv 2020. [CrossRef]

48. Long, Q.X.; Tang, X.J.; Shi, Q.L.; Li, Q.; Deng, H.J.; Yuan, J.; Hu, J.L.; Xu, W.; Zhang, Y.; Lv, F.J.; et al. Clinical and immunological assessment of asymptomatic SARS-CoV-2 infections. Nat. Med. 2020, 26, 1200-1204. [CrossRef] [PubMed]

49. Edridge, A.W.; Kaczorowska, J.M.; Hoste, A.C.; Bakker, M.; Klein, M.; Jebbink, M.F.; Matser, A.; Kinsella, C.; Rueda, P.; Prins, M.; et al. Coronavirus protective immunity is short-lasting. medRxiv 2020. [CrossRef]

50. Seow, J.; Graham, C.; Merrick, B.; Acors, S.; Steel, K.J.A.; Hemmings, O.; O’Bryne, A.; Kouphou, N.; Pickering, S.; Galao, R.; et al. Longitudinal evaluation and decline of antibody responses in SARS-CoV-2 infection. medRxiv 2020. [CrossRef]

51. Ng, O.W.; Chia, A.; Tan, A.T.; Jadi, R.S.; Leong, H.N.; Bertoletti, A.; Tan, Y.J. Memory T cell responses targeting the SARS coronavirus persist up to 11 years post-infection. Vaccine 2016, 34, 2008-2014. [CrossRef]

52. Feng, L.; Wang, Q.; Shan, C.; Yang, C.; Feng, Y.; Wu, J.; Liu, X.; Zhou, Y.; Jiang, R.; Hu, P.; et al. An adenovirus-vectored COVID-19 vaccine confers protection from SARS-COV-2 challenge in rhesus macaques. Nat. Commun. 2020, 11, 4207. [CrossRef]

53. Chu, D.K.W.; Pan, Y.; Cheng, S.M.S.; Hui, K.P.Y.; Krishnan, P.; Liu, Y.; Ng, D.Y.M.; Wan, C.K.C.; Yang, P.; Wang, Q.; et al. Molecular Diagnosis of a Novel Coronavirus (2019-nCoV) Causing an Outbreak of Pneumonia. Clin. Chem. 2020, 66, 549-555. [CrossRef] [PubMed] 